\title{
ODSJEK ZA INFORMACIJSKE ZNANOSTI NA FILOZOFSKOM FAKULTETU OSIJEK - ODAKLE SMO KRENULI I KAMO IDEMO?
}

\author{
DEPARTMENT OF INFORMATION SCIENCES \\ AT THE FACULTY OF HUMANITIES AND SOCIAL \\ SCIENCES OSIJEK - WHERE WE COME FROM \\ AND WHERE WE ARE GOING
}

\begin{abstract}
Filozofski fakultet
Sveučilište u Osijeku

sfaletar@ffos.hr

Kornelija Petr Balog

Filozofski fakultet

Sveučilište u Osijeku

kpetr@ffos.hr
\end{abstract}

Sanjica Faletar Tanacković

\author{
UDK / UDC [02:001.102:004]: \\ 005.336.5:37.093.5(497.5 Osijek)(091) \\ Pregledni rad / Review paper \\ Primljeno / Received: 28. 8. 2020. \\ Prihvaćeno / Accepted: 10. 11. 2020.
}

\section{Sažetak}

Cilj. Cilj je ovoga rada dati povijesni pregled djelovanja Odsjeka za informacijske znanosti Filozofskog fakulteta Osijek od njegovog osnutka do danas, s naglaskom na njegovu znanstvenu, nastavnu i stručnu djelatnost, studentsku populaciju te ishode učenja i kompetencije diplomiranih studenata.

Pristup. Na temelju postojećih dokumenata i radova koji govore o nastanku Odsjeka i njegovu djelovanju, ali i o studijskim programima i studentskim kompetencijama te zadovoljstvu studenata i poslodavaca, u radu se donose informacije o razlozima osnutka, načinima djelovanja i razvijanja Odsjeka te planovima za budući razvoj.

Vjesnik bibliotekara Hrvatske 63, 1-2(2020), 655-682 ISSN 0507-1925 
Rezultati. Rad donosi rezultate promišljanja autorica o aktivnostima Odsjeka, snazi, ali i prostorima za poboljšanje uočenih slabosti te pravcima budućeg razvoja.

Vrijednost. Vrijednost je ovog rada što bilježi brojne aktivnosti Odsjeka te na jednom mjestu opisuje njegov razvoj kroz protekle dva desetljeća. Kako Odsjek raste, on se i mijenja te je nužno da se sve te promjene trajno zabilježe.

Ključne riječi: Filozofski fakultet Osijek, informatologija, obrazovanje informacijskih stručnjaka, Odsjek za informacijske znanosti Osijek

\section{Summary}

Goal. The goal of this paper is to offer a historical overview of the activities of the Department of Information Sciences at the Faculty of Humanities and Social Sciences Osijek from its foundation until present. The paper is focused on the scientific, teaching and professional activities of the Department, student population and learning outcomes and competences of the graduate students.

Approach. On the basis of published (and internal) documentation and research and professional papers on the Department and its numerous outcomes (teaching, learning, research, communal) as well as the levels of satisfaction of both students and employers, the paper illustrates the motivation for foundation of the Department, its past and present activities and plans for development.

Results. The paper presents results of the authors' view of Department's activities, its strong sides, possible areas of improvement and directions of future development.

Value. This paper enumerates numerous Department's activities and describes them and their historical background in one place. As the Department grows, it changes and it is imperative that those changes remain described and published.

Keywords: Department of Information Sciences Osijek, Education of information professionals, Faculty of Humanities and Social Sciences Osijek, informatology, 


\section{Uvodna razmatranja}

Postojanje sustavnog obrazovanja ključno je za razvoj i ugled bilo koje profesije, pa tako i knjižničarstva. Doduše, potreba za dokazivanjem da je knjižničarstvo profesija vremenom nije jenjala te i danas nailazimo radove autora koji različitim argumentima dokazuju da knjižničarstvo doista jest profesija. ${ }^{1}$ Prva knjižnična škola pokrenuta je 1880. godine na Sveučilištu Columbia naporima Melvila Deweya, dok je primjerice u Velikoj Britaniji obrazovanje pokrenuto nekoliko godina kasnije, na prijelazu 19. u 20. stoljeće i to na dvije institucije istovremeno - University College London i London School of Economics, ${ }^{2}$ a prva sveučilišna Katedra za knjižničarstvo osnovana je 1887. u Göttingenu u Njemačkoj, pri čemu je knjižničarstvo tumačeno kao opća povijesna disciplina. ${ }^{3} \mathrm{U}$ osnovi, status obrazovanja knjižničara u različitim zemljama svijeta odražava stupanj razvoja knjižnične i informacijske djelatnosti u pojedinoj zemlji s jedne strane te razvijenost obrazovnog sustava s druge. ${ }^{4}$

S obzirom na hrvatsku turbulentnu povijest, ne začuđuje što je prvi sustavni oblik obrazovanja za knjižničare (zamišljen, između ostalog, i kao obrazovni poligon za kasnije edukatore i sveučilišne nastavnike budućih studenata knjižničnih i informacijskih znanosti) započeo tek u drugoj polovici 20. stoljeća. Naime, poslijediplomski studij knjižničarstva, dokumentacije i informacijskih znanosti pokrenut je 1961. godine na Prirodoslovno-matematičkom fakultetu Sveučilišta u Zagrebu zaslugama i zalaganjem Bože Težaka. Program je upisivao nove studente sve do početka 1990-ih kada je ugašen. ${ }^{5}$ Kada se stvorila jezgra prvih sveučilišnih nastavnika 1976/1977. godine pokrenut je i prvi dvogodišnji dopunski studij knjižničarstva na Filozofskom fakultetu u Zagrebu koji je 1986. godine prerastao u četverogodišnji studij u području informacijskih znanosti te od tada obrazuje knjižničare, arhiviste i muzeologe, ${ }^{6}$ a kasnije i druge profile informacijskih stručnjaka. ${ }^{7}$ Dugo je godina taj studij bio jedini sveučilišni studij knjižničarstva, da bi

1 Usp. npr. Rubin, R. E. Foundations of library and information science. London: Facet, 2016. Str. 281-284. U Hrvatskoj je o knjižničarstvu kao profesiji pisala Tatjana Aparac-Jelušić u knjizi Teorijske osnove knjižnične znanosti. Usp. Aparac-Gazivoda, T. Teorijske osnove knjižnične znanosti. Zagreb: Filozofski fakultet, Zavod za informacijske studije Odsjeka za informacijske znanosti, 1993. Str. 17-19.

2 Pors, N. O. Library education. // International Encyclopedia of Information and Library Science / ed. by J. Feather and P. Sturges. London; New York: Routledge, 2003. Str. 382.

3 Usp. Aparac-Gazivoda, T. Nav. dj., str. 22.

4 Usp. Pors, N. O. Nav. dj., str. 381.

5 Horvat, A.; J. Kolanović; V. Zgaga. Croatia: Libraries, archives and museums. // Encyclopedia of Library and Information Sciences / ed. by M. J. Bates, M. N. Maack. 3rd. ed. Clevelnad: CRC Press, 2009. Str. 1350.

6 Isto.

7 O obrazovanju knjižničara, poglavito na Filozofskom fakultetu u Zagrebu napisano je nekoliko radova. Usp. Horvat, A. Školovanje knjižničara u svjetlu europskih normi. // Vjesnik bibliote- 
se krajem 20. stoljeća počeli osnivati studiji i na drugim sveučilištima u Hrvatskoj. U ovom ćemo radu prikazati nastanak i razvoj sveučilišnog studija informacijskih i komunikacijskih znanosti na Filozofskom fakultetu Sveučilišta J. J. Strossmayera u Osijeku.

\section{Obrazovanje knjižničara u Osijeku prije osnutka Katedre za knjižničarstvo na Filozofskom fakultetu u Osijeku}

Osnutak Katedre za knjižničarstvo na Filozofskom fakultetu u Osijeku u akademskoj godini 1998/1999. ne označava i početak zanimanja za obrazovanje stručnjaka iz te struke u Osijeku, odnosno Slavoniji, Baranji i Srijemu. Naime, knjižničarstvo se prvi puta našlo u nastavnom programu studija hrvatskog jezika i književnosti od 1968/1969. do 1976/1977. na tadašnjoj Pedagoškoj akademiji. ${ }^{8}$ Tada je to bilo u vrlo skromnom obliku jednog jednosemestralnog kolegija, no s obzirom na to da su brojni nastavnici hrvatskog jezika vrlo često dobivali zadatke vođenja školskih knjižnica, tim im se kolegijem željelo pomoći, iako su i sami kreatori nastavnog programa bili svjesni da je opseg kolegija „štur i jednostran“.9

Potpuniji i zaokruženiji program obuke budućih knjižničara organiziran je poslije 1977. godine. Od 1977/1978. do 1989/1990. osječki je centar za usmjereno obrazovanje (CUO „Braća Ribar“) školovao „suradnike u INDOK djelatnosti knjižničara" na razini srednjoškolskog obrazovanja. ${ }^{10}$ Budući da se u navedenom vremenu srednjoškolsko obrazovanje odvijalo u okvirima takozvane „Šuvarove reforme“ ${ }_{11}^{11}$ prve su dvije godine u svim srednjim školama bile općeg tipa i nudile nestručne predmete, dok se usmjeravanje prema strukama odvijalo upisivanjem

kara Hrvatske 48, 1(2005), str. 101-106; Horvat, A. Obrazovanie i vospituvanje bibliotekari na početokot na noviot vek. // Bibliotekarska iskra 17, 1/2(1999), str. 37-41; Horvat, A. Školovanje i izobrazba bibliotekara pred novim tisućljećem. // Vjesnik bibliotekara Hrvatske 40, 1/2(1997), str. 131-138; Horvat, A. Skolovanje knjižničara u Hrvatskoj. // Vjesnik bibliotekara Hrvatske 39, 1/2(1996), str. 133-142; Aparac-Gazivoda, T.; A. Horvat. Dodiplomsko obrazovanje bibliotečnih i ostalih informacijskih stručnjaka. // Obrazovanje za tehnološki razvoj:Savjetovanje Zagreb: Savez inženjera i tehničara, 1985. Str. 181-188.

8 Usp. Erl, V.; K. Petr. Studij bibliotekarstva na Pedagoškom fakultetu u Osijeku: da ili ne? // Vjesnik bibliotekara Hrvatske 39, 1-2(1996), str. 164.

9 Usp. Izvještaj o radu u školskoj godini 1968./69. Osijek: Pedagoška akademija, 1969. Str. 15.

10 Radman, Lj. Osvrt na školovanje knjižničara u Osijeku od 1977. do 1990. godine. // Knjižničarstvo 1, 1(1997), str. [64]. [citirano: 2018-08-28]. Dostupno na: http://www.knjiznicarstvo.com. hr/wp-content/uploads/2012/06/6_Radman_1997_1.pdf.

11 Stipe Šuvar, bivši republički sekretar (ministar) za prosvjetu i kulturu u vremenu od 1974. do 1982. zapamćen je po zadnjoj reformi školstva u Hrvatskoj prije trenutačne kurikularne reforme. Kroz njegovu je reformu ponuđen nov koncept srednje škole koji je obrazovanje podijelio na pripremnu i obrazovnu fazu školovanja za pojedina zanimanja. Jedan od važnih trenutaka njegove reforme bio je i naglasak na stručnoj praksi. Usp. Šuvar, S. Zagreb: Školska knjiga, 1977. 
u 3. godinu. Shodno tomu, knjižničarski su se predmeti predavali tijekom 3. i 4. godine srednje škole. ${ }^{12}$

Osnutkom Pedagoškog fakulteta u Osijeku obnavljaju se nastojanja da se obrazovanje knjižničara utemelji na visokoškolskoj razini, no nažalost, nedostatak stručnih kadrova u Osijeku i društveno-političke promjene praćene ratnim vihorom onemogućavaju ostvarenje te zamisli sve do kraja 90-ih godina 20. stoljeća.

\section{Osnutak Katedre za Knjižničarstvo}

Kao što se iz prethodnog poglavlja moglo vidjeti, u Osijeku je dugo bila izražena želja za pokretanjem formalnog obrazovanja knjižničara. Razlozi za to bili su mnogostruki: postojala je potreba za akademski obrazovanim knjižničarima, željelo se umanjiti problem putovanja u Zagreb za ostvarivanjem kvalitetne naobrazbe u centralizirano postavljenom modelu obrazovanja knjižničara. Pored toga, pojavila se potreba za većim brojem nastavnika u znanstveno-nastavnim zvanjima (što se moglo ostvariti samo formalnom naobrazbom), a pojavila se i potreba za profiliranjem studija u odnosu na Zagreb zbog niza novih tema koje su se javljale unutar informacijskih znanosti.

Osnutku Katedre prethodilo je istraživanje iz 1996. godine provedeno među četrnaest gimnazija u Slavoniji, Baranji i Srijemu. U tom se istraživanju, između ostalog, ispitivala zainteresiranost maturanata za upisivanje studija knjižničarstva, te se utvrdilo da bi broj potencijalnih studenata porastao kad bi bilo mogućnosti da se studij organizira na Pedagoškom fakultetu u Osijeku. ${ }^{13}$ To je istraživanje poslužilo kao polazna točka pripremama za pokretanje dodiplomskog četverogodišnjeg dvopredmetnog studija knjižničarstva na tadašnjem Pedagoškom fakultetu u Osijeku. ${ }^{14}$ Katedra je osnovana naporima Vere Erl koja je bila i njezina prva predsjednica, a nastava se u početku izvodila velikim dijelom uz pomoć sveučilišsnih nastavnika s Odsjeka za informacijske i komunikacijske znanosti Filozofskog fakulteta u Zagrebu te kolega knjižničara zaposlenih u osječkim knjižnicama. ${ }^{15}$

12 Lj. Radman navodi sljedeće nazive predmeta koji su tada bili u nastavnom programu: Povijest knjige i knjižnica, Bibliografija, Bibliotečno poslovanje, Primjena kompjutora u biblioteci, Praktičan rad (Katalogizacija i klasifikacija, Zaštita i čuvanje bibliotečne građe). Usp. Radman, Lj. Nav. dj.

13 Usp. isto, str. 167.

14 U početku je bila moguća samo kombinacija s hrvatskim jezikom i književnošću, od akademske 2003./2004. i s pedagogijom, a 2004/2005. studij se otvorio kombinacijama sa svim ostalim programima na Fakultetu.

15 U početku je na Katedri bila zaposlena samo jedna osoba, Vera Erl, kao viši predavač, dok je 2000. godine na katedru kao asistentica pristigla Kornelija Petr. S tako malim brojem zaposlenih djelatnika, ostala se nastava odvijala uz angažman sveučilišnih nastavnika s Filozofskog fakulteta u Zagrebu: Aleksandra Stipčevića, Aleksandre Horvat, Jadranke Lasić-Lazić i Tatjane Aparac-Jelušić te knjižničara iz Osijeka: Dragutina Katalenca, Svjetlane Mokriš, Marine Vinaj, Ljubice Radman, Jasmine Lovrinčević, Lidije Vukić, Silve Pavlinić i Kate Ivić. 
Nakon upisa prvih redovitih studenata u akademskoj godini 1998/1999., Katedra upisuje prve izvanredne studente u akademskoj 1999/2000. ${ }^{16}$ Na poziv zadarskih knjižničara i uprave novoosnovanog Sveučilišta u Zadru, Katedra pokreće izvanredni dislocirani studij knjižničarstva i u Zadru u akademskoj godini 2001/2002., ${ }^{17}$ dok u akademskoj 2003/2004. pokreće dislocirani redoviti studij u Vinkovcima. ${ }^{18}$ Sve te dodatne nastavne aktivnosti Katedre prestaju prelaskom na Bolonjski proces u akademskoj godini 2005/2006. Diplomirani studenti na svim programima stjecali su naziv „diplomirani knjižničar“.

Prva je godina djelovanja Katedre obilovala brojnim izazovima i naporima da se nastava organizira i izvede u potpunosti s glavninom nastavnika koji su nastavu izvodili kao vanjski suradnici. Takva situacija nipošto nije bila jednostavna ni za tadašnju predsjednicu Katedre Veru Erl, ni za vanjske suradnike, a ni za studente. Stoga se pojačano radilo na upošljavanju novih djelatnika, te su 2001. godine na Katedru pristigli kao stalno zaposleni djelatnici Tatjana Aparac-Jelušić i Srećko Jelušić. Njihovim je dolaskom započelo razdoblje rasta i razvijanja Katedre, koja je vrlo brzo, već od akademske godine 2005/2006., prerasla u Odsjek za informacijske znanosti. O Odsjeku i njegovom razvoju bit će više riječi u sljedećem poglavlju.

\section{Odsjek za informacijske znanosti}

\subsection{Općenito o Odsjeku}

Odsjek se s vremenom širio i upošljavao nove djelatnike. Ono što je na početku započelo kao Katedra sa samo jednom zaposlenom osobom izraslo je u visoko strukturiran i profiliran Odsjek. Trenutno je na Odsjeku zaposleno 22 djelatnika $^{19}$ (5 redovitih profesora, 3 izvanredna profesora, 9 docenata, 1 poslijedoktorand, 3 asistenta i 1 predavačica) koji su raspoređeni na četiri katedre: ${ }^{20}$

16 Izvanredni se studij ugasio prelaskom na Bolonjski sustav obrazovanja.

17 Studij se prekida osnivanjem Odjela za knjižničarstvo na Sveučilištu u Zadru 2004. godine. Usp. Odjel za informacijske znanosti: samoanaliza. Zadar: Sveučilište, 2014. [citirano: 201808-28]. Dostupno na: http://iz.unizd.hr/Portals/70/docs_stari_web/sa_starog_weba_ZG/SAMOANALIZA_OIZ_FIN_potpis.pdf.

18 Usp. Petr Balog, K. Osnutak Katedre za knjižničarstvo, Pedagoški fakultet Osijek: (ak. god. 1998/1999.). // Knjižničarstvo 13-14, 1-2(2009-2010), str. 27.

19 U proljeće 2018. godine na Odsjek su pristigle četiri djelatnice s Odjela za kulturologiju smjer knjižničarstvo Sveučilišta u Osijeku. S obzirom na to da je Odjelu prijetilo uskraćivanje dopusnice od strane Agencije za znanost i visoko obrazovanje, uprava je Sveučilišta odlučila da se u potpunosti zatvori smjer knjižničarstvo, dok su ostala dva smjera (medijska kultura i kulturni menadžment) postali Odsjekom za kulturologiju na Akademiji za umjetnost i kulturu Sveučilišta u Osijeku. Djelatnici Odjela za kulturologiju koji nisu svoje novo radno mjesto našli na Akademiji, Odlukom su Sveučilišta raspoređeni na nova radna mjesta na ostale sastavnice Sveučilišta.

20 Stanje 24. srpnja 2020. 
- Katedra za upravljanje knjižnicama i organizaciju informacija

- predsjednica Katedre: prof. dr. sc. Gordana Dukić; članovi: prof. dr. sc. Kornelija Petr Balog, doc. dr. sc. Ivana Martinović, doc. dr. sc. Kristina Feldvari, doc. dr. sc. Snježana Stanarević

- Katedra za teoriju informacijskih znanosti

- predsjednica Katedre: izv. prof. dr. sc. Anita Papić; članovi: izv. prof. dr. sc. Boris Badurina, izv. prof. dr. sc. Boris Bosančić, doc. dr. sc. Milijana Mičunović, doc. dr. sc. Marija Erl Šafar, doc. dr. sc. Gordana Lesinger, dr. sc. Tamara Zadravec, predavačica, Tihana Lubina, poslijedoktorandica i Mirna Gilman Ranogajec, asistentica;

- Katedra za zaštitu pisane baštine i suradnju baštinskih ustanova

- predsjednik Katedre: prof. dr. sc. Damir Hasenay; članovi: prof. dr. sc. Sanjica Faletar Tanacković, doc. dr. sc. Darko Lacović i Ines Horvat, asistentica;

- Katedra za povijest knjige, nakladništvo i knjižarstvo

- predsjednik Katedre: prof. dr. sc. Zoran Velagić; članovi: izv. prof. Jelena Lakuš, doc. dr. sc. Josipa Selthofer, doc. dr. sc. Tomislav Jakopec i Ines Hocenski, asistentica.

Prva voditeljica Odsjeka je bila Vera Erl, koja je ujedno i najzaslužnija za pokretanje studija. Trenutno se na čelu Odsjeka nalazi Boris Badurina, a za sljedeće mandatno razdoblje za voditelja izabran je Boris Bosančić. U tablici 1 navedene su osobe koje su bile na čelu Odsjeka od njegovih početaka (Katedra za knjižničarstvo) do danas.

Tablica 1. Voditelji na Odsjeku za informacijske znanosti

\begin{tabular}{|l|l|}
\hline Period & Voditelj \\
\hline $1998-2001$. & Vera Erl \\
\hline $2001-2008$. & Tatjana Aparac-Jelušić \\
\hline $2008-2010$. & Damir Hasenay \\
\hline $2010-2012$. & Zoran Velagić \\
\hline $2012-2014$. & Kornelija Petr Balog \\
\hline $2014-2015$. & Maja Krtalić \\
\hline $2015-2017$. & Gordana Dukić \\
\hline $2017-2020$. & Boris Badurina \\
\hline $2020-2022$. & Boris Bosančić \\
\hline
\end{tabular}


Članovi Odsjeka dobili su brojne domaće i međunarodne nagrade koje svjedoče o kvaliteti njihova znanstvenog, nastavnog i/ili stručnog rada. Primjerice, čak šest nastavnika na Odsjeku dobitnici su nagrade Eva Verona koju Hrvatsko knjižničarsko društvo dodjeljuje mladim knjižničarima za inovativnosti i izniman doprinos razvoju struke. U tablici 2 navedene su sve nagrade i priznanja koja su djelatnici Odsjeka dobili za svoj nastavni, stručni ili znanstveni rad. ${ }^{21}$

Tablica 2. Nagrađeni nastavnici Odsjeka

\begin{tabular}{|l|l|l|}
\hline Nastavnik & Nagrada & Godina \\
\hline Kornelija Petr Balog & Nagrada „Eva Verona“ & 1998. \\
\hline $\begin{array}{l}\text { Boris Badurina, } \\
\text { Sanjica Faletar } \\
\text { Tanacković }\end{array}$ & Nagrada „Eva Verona“ & 2006. \\
\hline $\begin{array}{l}\text { Tatjana Aparac } \\
\text { Jelušić }\end{array}$ & $\begin{array}{l}\text { Nagrada Thompson ISI’s Outstanding Infor- } \\
\text { mation Science Teacher of the Year(American } \\
\text { Society for Information Science and Technol- } \\
\text { ogy - ASIST) }\end{array}$ & 2006. \\
\hline Vera Erl & Povelja „Marija Malbaša“ & 2006. \\
\hline Boris Bosančić, \\
$\begin{array}{l}\text { Boris Badurina i } \\
\text { Kornelija Petr }\end{array}$ & $\begin{array}{l}\text { Nagrada za najbolji poster na konferenciji } \\
\text { Libraries in the Digital Age (LIDA) } \\
\text { Bosančić, B.; B. Badurina; K. Petr; M. } \\
\text { Gracek; K. Feldvari; I. Knežević; G. Vučkov- } \\
\text { ić; F. Horvat. Students creating digital re- } \\
\text { pository: students’ practical placement at the } \\
\text { department of information sciences, faculty } \\
\text { of philosophy in Osijek. }\end{array}$ & \\
\hline Maja Krtalić & Nagrada „Eva Verona“” & 2007. \\
\hline Kornelija Petr Balog & $\begin{array}{l}\text { Highly Commended Award online baze Em- } \\
\text { erald za rad: } \\
\text { Petr Balog, K. Measuring Croatian public } \\
\text { and academic library culture: interviews with } \\
\text { library directors. // PerformanceMeasure- }\end{array}$ & 2008. \\
\hline
\end{tabular}

21 Tablica daje podatke samo za razdoblje u kojem su dobitnici nagrada i priznanja bili zaposlenici Odsjeka za informacijske znanosti Filozofskog fakulteta Osijek.

22 Prva osoba kojoj je dodijeljena ova nagrada, a koja nije bila američka državljanka. 


\begin{tabular}{|c|c|c|}
\hline Nastavnik & Nagrada & Godina \\
\hline & $\begin{array}{l}\text { Nagrada za najbolji poster na konferenciji } \\
\text { Libraries in the Digital Age (LIDA): }\end{array}$ & \\
\hline $\begin{array}{l}\text { Anita Papić i Josipa } \\
\text { Selthofer }\end{array}$ & $\begin{array}{l}\text { Papić, A.; J. Selthofer; I. Ignjačić. Digital } \\
\text { native’s (in)formal learning environment }\end{array}$ & 2010. \\
\hline $\begin{array}{l}\text { Snježana Stanarević } \\
\text { Katavić }\end{array}$ & $\begin{array}{l}\text { Nagrada Highly Commended Award of the } \\
2013 \text { Emerald/EFMD Outstanding Doctoral } \\
\text { Research online baze Emerald za doktorsku } \\
\text { disertaciju pod naslovom "Information needs } \\
\text { and information behavior of patients with rare } \\
\text { chronic diseases in the Republic of Croatia” }\end{array}$ & 2013. \\
\hline Tomislav Jakopec & $\begin{array}{l}\text { Pobjednik 2. osječkog hackathona održanog u } \\
\text { organizaciji Osijek Software City }\end{array}$ & 2013. \\
\hline Tomislav Jakopec & $\begin{array}{l}\text { Pobjednik 3. osječkog hackathona održanog u } \\
\text { organizaciji Osijek Software City }\end{array}$ & 2014. \\
\hline Ivana Martinović & Nagrada „Eva Verona“ & 2014. \\
\hline $\begin{array}{l}\text { Snježana Stanarević } \\
\text { Katavić }\end{array}$ & Nagrada „Eva Verona“ & 2016. \\
\hline $\begin{array}{l}\text { Darko Lacović, } \\
\text { Sanjica Faletar } \\
\text { Tanacković }\end{array}$ & $\begin{array}{l}\text { Nagrada za najbolji poster na konferenciji } \\
\text { Libraries in the Digital Age (LIDA): } \\
\text { Gašo, G.; D. Lacović; S. Faletar-Tanacković. } \\
\text { Academic Staff and Use of Electronic Library } \\
\text { Resources: Preliminary Results of the Study } \\
\text { at the Faculty of Humanities and Social Sci- } \\
\text { ences in Osijek }\end{array}$ & 2016. \\
\hline $\begin{array}{l}\text { Milijana Mičunović, } \\
\text { Ivana Martinović }\end{array}$ & $\begin{array}{l}\text { Pohvala Filozofskog fakulteta u Osijeku za iz- } \\
\text { vrstan nastavni rad. }\end{array}$ & $\begin{array}{l}\text { ak. god. } \\
\text { 2016/2017. }\end{array}$ \\
\hline Boris Bosančić & $\begin{array}{l}\text { Nagrada u kategoriji “Outstanding papers” } \\
\text { online baze Emerald za rad: Bosančić, B. } \\
\text { Information in the knowledge acquisition } \\
\text { process. // Journal of Documentation 72, } \\
\text { 5(2016), 930-960. }\end{array}$ & 2017. \\
\hline $\begin{array}{l}\text { Kornelija Petr Balog } \\
\text { i Boris Badurina }\end{array}$ & $\begin{array}{l}\text { Highly Commended Award online baze Em- } \\
\text { erald za rad: Petr Balog, K.; B. Badurina. } \\
\text { Students of humanities and social sciences } \\
\text { and e-democracy. // Information and Learning } \\
\text { Science 118, 5(2017), 266-279. }\end{array}$ & 2018. \\
\hline
\end{tabular}


Djelatnici Odsjeka prepoznati su i na nacionalnoj razini te su uključeni u rad Matičnih odbora (u sazivu 2017-2021.):

- Damir Hasenay (MO za interdisciplinarno područje - znanost, umjetnost)

- Kornelija Petr Balog (MO za polje informacijskih i komunikacijskih znanosti).

Iz redova nastavnika nekoliko ih je bilo uključeno u upravljanje Filozofskim fakultetom i to:

- 2005-2009. - Kornelija Petr Balog, Prodekanica za razvojno-stručni rad

- 2009-2014. - Damir Hasenay, Prodekan za studijske programe i studente

\subsection{Nastavna djelatnosti}

Akademska godina 2005/2006. predstavlja godinu prekretnicu u programskoj i organizacijskoj strukturi tadašnje Katedre. Katedra mijenja svoj naziv i postaje Odsjek za informacijske znanosti označavajući tom promjenom ne samo da je brojčano prerasla razinu katedre nego i da je došlo do značajnih odmaka u sadržajnoj strukturi nastavnih sadržaja koji su se predavali studentima. Umjesto naglaska na tradicionalne, isključivo knjižničarske teme i sadržaje, od te se akademske godine sadržaji proširuju i uključuju veći broj tema iz područja informacijskih znanosti, informacijske tehnologije te nakladništva. Ta je promjena koincidirala s procesom uvođenja Bolonjskog procesa u visokoškolsko obrazovanje u Republici Hrvatskoj te s tom nužnom promjenom prof. dr. sc. Tatjana Aparac-Jelušić, koja preuzima voditeljstvo Odsjeka i glavna je autorica novog bolonjskog nastavnog plana i programa informatologije, ${ }^{23}$ uvodi i značajne promjene u samu strukturu studija. Bolonjski proces ne samo da je za staru Katedru značio drugačiju dinamiku studiranja $(2+3$ godina) nego je i uz promjene sadržajnog tipa označio i izostavljanje naziva „knjižničar“ iz naziva studija i diplome završenih studenata. ${ }^{24}$ Dodatna je promjena i ta da je s uvođenjem novog plana i programa informatologije ukinuta dotadašnja dvopredmetnost studija. Od te su akademske godine diplomirani studenti dobili naziv prvostupnik, odnosno magistar informatologije. $\mathrm{S}$ novim programima došlo je i do promjene naziva diplomiranih studenata $-\mathrm{s}$ obzirom na velike promjene u sadržaju nastavnog programa smatralo se da termin „diplomirani knjižničar" više ne može dostatno opisati znanja, vještine i kompe-

${ }^{23}$ Usp. Nastavni plan i program studija informatologije: prihvaćen na sjednici Nacionalnog vijeća za visoku naobrazbu, 20. lipnja 2005. Osijek: Filozofski fakultet, 2005. [citirano: 2018-0829]. Dostupno na: file://C:/Users/Korisnik/Downloads/Nastavni\%20plan\%20i\%20program\%20 studija\%20informatologije\%20(1).pdf.

24 Do te je odluke došlo nakon brojnih razgovora sa studentima koji su se vodili na kolokvijima Katedre/Odsjeka te na trima okruglim stolovima (25. listopada 2002., 15. travnja 2004. te 16. ožujka 2005.). Tim su prigodama studenti iskazivali svoje nezadovoljstvo percepcijom struke i njih kao knjižničara u društvu te su smatrali da je prvi korak u promjeni te nezadovoljavajuće situacije izbacivanje naziva „knjižničar“ iz naziva studija. Usp. Nastavni plan. Nav. dj., str. 12. 
tencije novodiplomiranih studenata. Dvojilo se hoće li se koristiti termin „informacijski stručnjak“ (prema engleskoj sintagmi information specialist) ili „informatolog", te se za potonji naziv odlučilo jer se smatralo da je uporaba naziva za profesiju sastavljena od dvije riječi nepodesna te da termin ,informatolog“" slijedi praksu izvođenja naziva drugih profesija (npr. sociolog, pedagog i sl.). Termin ,,informatolog“ implicira proučavanje informacija i djelovanje u širokom spektru informacijsko-komunikacijskih aktivnosti, a njegove kompetencije temelje se na temeljnim kompetencijama knjižničara koje su proširene znanjima i vještinama potrebnim za upravljanje informacijskom i komunikacijskom tehnologijom te digitalnim izvorima. ${ }^{25}$

Akademske godine 2008/2009. Odsjek je u suradnji s Odjelom za knjižničarstvo Sveučilišta u Zadru (danas, Odjel za informacijske znanosti) te Odsjekom za kulturnu baštinu i izvedbene umjetnosti Sveučilišta u Parmi, Italija, pokrenuo združeni diplomski studij Pisana baština u digitalnome okruženju koji je bio otvoren i stranim studentima. ${ }^{26}$ Studij se ugasio nakon upisane dvije generacije studenata, prije svega zbog nedorečenog pravnog okvira za organizaciju združenih studija.

U akademskoj godini 2015/2016. godini Odsjek pristupa reviziji diplomskog studija te on postaje dvopredmetan, a studenti mogu odabrati kombinacije triju modula: informatologije, informacijske tehnologije i nakladništva. ${ }^{27}$ Cilj tih promjena u odnosu na dotadašnji jednopredmetni diplomski studij informatologije bio je izdvojiti tri temeljna stupa dotadašnjeg studija (nakladništvo, informatologiju i informacijsku tehnologiju) u tri zasebna studija koji se mogu međusobno kombinirati u dvopredmetnoj kombinaciji. Odsjek je smatrao da studenti time dobivaju dvije kvalifikacije i sadržajno jače i kvalitetnije obrazovanje u polju informacijskih znanosti. Konačni cilj izmjena studijskih programa bio je obrazovati stručnjake koji će kombinacijom studija Informatologije, Nakladništva i Informacijske tehnologije postati informacijski stručnjaci koji mogu tradicionalne vještine rada u informacijskom okruženju kompetentno iskoristiti kreirajući i primjenjujući sve prednosti informacijske tehnologije te time biti atraktivniji na tržištu rada. Pokretanje svih triju studija poduprle su organizacije s tržišta rada. ${ }^{28}$

25 Usp. Aparac-Jelušić, T. Kompetencije knjižničara i informatologa: izazovi u vremenu društvenih i kulturnih promjena. // Organizacija znanja 24, 1-2(2019). [citirano: 2020-07-22]. Dostupno na: https://www.cobiss.si/OZ/PDF/OZ_2019_1_2_final/1924001_Aparac_Jelusic.pdf.

26 Usp. Hasenay, D. Odsjek za informacijske znanosti. // Filozofski fakultet. Osijek: Filozofski fakultet, 2010. Str. 64.

27 Studij nakladništva iznimka je jer se, osim za studente koji kao drugi predmet imaju informatologiju ili informacijsku tehnologiju, dodatno kombinira i sa studijima njemačkog i engleskog jezika i književnosti.

${ }^{28}$ Usp. Odsjek za informacijske znanosti. Studijski programi. // Filozofski fakultet Osijek. [citirano:2018-08-30]. Dostupno na: http://www.ffos.unios.hr/infoznanosti/studijski-programi. 
Od 2017/2018. godine Odsjek aktivno radi na pripremi novih i revidiranih programa preddiplomskog studija. U pripremi su dvije inačice: revidirani jednopredmetni studij informatologije te novi prijedlog dvopredmetnog preddiplomskog studija informatologije. Prijedlozi programa dobili su pozitivne recenzije te će se u akademskoj godini 2020/2021. upisati prva generacija studenata koja će studirati po novim revidiranim programima preddiplomskog studija. U revidiranje dotadašnjih preddiplomskih programa ušlo se prvenstveno zato da se programi osuvremene novim spoznajama te da se studentima ponude programi koji će bolje odgovarati potrebama tržišta. Dodatni je razlog bio taj da se uvede dvopredmetnost koja se izgubila prelaskom na jednopredmetni bolonjski studij informatologije (a koja je postojala u ranijem programu školovanja diplomiranih knjižničara). Informacijske ustanove uvijek rado upošljavaju djelatnike sa znanjima drugih predmetnih područja, te je Odsjek smatrao da će vraćanjem dvopredmetnosti povećati konkurentnost naših diplomiranih studenata na tržištu rada Republike Hrvatske, ali i izvan nje.

Godine 2009. pokrenut je doktorski studij „Društvo znanja i prijenos informacija“ pri Sveučilištu u Zadru, dok je njegov sunositelj bio Odsjek za informacijske znanosti Filozofskog fakulteta u Osijeku. ${ }^{29} \mathrm{Uz}$ taj studij, u Hrvatskoj se nudi doktorski studij informacijskih i komunikacijskih znanosti na Filozofskom fakultetu u Zagrebu. Zadarski doktorski studij do sada je stekao zavidan ugled u zajednici hrvatskih informacijskih stručnjaka.

Zahvaljujući bogatoj suradnji koju Odsjek od 2005. godine razvija s renomiranim stranim sveučilištima, na Odsjeku je boravio značajan broj sveučilišnih profesora i znanstvenika (npr. Bob Hayes (UCLA, SAD), Nicholas Belkin, Marija Dalbello, Carol Kuhlthau i Tefko Saracevic (Rutgers University, SAD), Sanda Erdelez (University of Missouri, SAD), Coleen Cool (City University New York, SAD), Terry Weech (University of Illinois, Urbana-Champaign) te Paul Sturges (Loughborough University, UK), koji su svojim predavanjima i radionicama obogatili nastavne procese. U posljednjih pet akademskih godina gostujući predavači na Odsjeku u pravilu dolaze u okviru Erasmus+ programa iz europskih zemalja (Finska, Mađarska, Portugal, Švedska i Turska). Istovremeno, i nastavnici s Odsjeka sudjeluju u nastavi na brojnim europskim sveučilištima (npr. University of Borås, Švedska, Polytechnic Institute of Porto, Portugal, Vilnius University, Litva, Université Libre de Bruxelles, Belgija, Abo Akademi University, Finska itd.).

U okviru Erasmus ${ }^{+}$programa EINFOSE, čiji je glavni koordinator bio Odsjek, u Osijeku je od 1. do 6. 9. 2019. održana treća Europska ljetna škola informacijskih znanosti (ESSIS) za 24 studenata iz 6 europskih zemalja, na kojoj su uz domaće nastavnike predavanja držali i nastavnici iz Bosne i Hercegovine, Italije, Njemačke, Rusije i Španjolske. ${ }^{30}$

29 Aparac-Jelušić, T. Novi. Nav. dj., str. 492.

30 Nastavnici s Odsjeka sudjelovali su i na prve dvije Europske ljetne škole informacijskih znanosti (ESSIS) koje su održane 2017. u Njemačkoj te 2018. godine u Austriji. 
Uz gostujuća predavanja stranih stručnjaka, na Odsjeku gostuju i domaći stručnjaci iz prakse koji često dolaze iz redova bivših studenata, a redovna se nastava redovito obogaćuje terenskom nastavom u okviru koje studenti posjećuju značajne domaće i strane informacijske i baštinske ustanove i upoznaju se s njihovim praksama i djelatnostima (npr. Nacionalna i sveučilišna knjižnica u Zagrebu, Hrvatski državni arhiv, Muzej Slavonije, British Library u Londonu itd.).

\subsection{Znanstvena aktivnost Odsjeka}

Članovi Odsjeka uključeni su, kao voditelji ili suradnici, u rad brojnih nacionalnih i međunarodnih kompetitivnih i znanstvenih projekata, među kojima se posebno ističu oni koje financira Europska Unija i Sveučilište J. J. Strossmayera u Osijeku. U te se projekte, kada je to god moguće, uključuju i studenti s Odsjeka koji u njima produbljuju stečena stručna i metodološka znanja. U nastavku se navode, kronološkim slijedom prema godini početka, projekti koji se provode ili su se provodili u posljednjih pet godina (tablica 3).

Tablica 3. Znanstveni projekti na Odsjeku od 2015. do 2020.

\begin{tabular}{|l|l|l|}
\hline Naziv & Projekt & Trajanje \\
\hline $\begin{array}{l}\text { Informacijske potrebe oboljelih od Alzhei- } \\
\text { merove bolesti i članova njihovih obitelji }\end{array}$ & UNIOS ZUP 2019 -76 & 2019-2020. \\
\hline $\begin{array}{l}\text { Archeological Practices and Knowledge } \\
\text { Work In the Digital Environment (ARK- } \\
\text { WORK) }\end{array}$ & COST CA15201 & $2016-2020$. \\
\hline $\begin{array}{l}\text { European Information Sciences Educa- } \\
\text { tion: Encouraging Mobility and Learning } \\
\text { Outcomes Harmonization (EINFOSE) }\end{array}$ & $\begin{array}{l}\text { Erasmus+ Key Action 2 } \\
\text { - Strategic Partnerships } \\
\text { for Higher Education }\end{array}$ & $2016-2018$. \\
\hline $\begin{array}{l}\text { Istraživanje informacijskog ponašanja } \\
\text { mladih pri pretraživanju zdravstvenih in- } \\
\text { formacija putem mobilnih uređaja }\end{array}$ & UNIOS 2016 & $2016-2017$. \\
\hline $\begin{array}{l}\text { Virtualna okolina i percepcija stvarnosti: } \\
\text { istraživanje utjecaja strukture i karakter- } \\
\text { istika virtualnog okruženja na ponašanje } \\
\text { mladih }\end{array}$ & UNIOS 2015 & $2015-2016$. \\
\hline $\begin{array}{l}\text { High-Performance Modelling and Simu- } \\
\text { lation for Big Data Applications (cHiPSet) }\end{array}$ & COST IC1406 & $2015-2019$. \\
\hline $\begin{array}{l}\text { Evolution of reading in the age of digitiza- } \\
\text { tion (E-READ) }\end{array}$ & COST IS1404 & $2014-2018$. \\
\hline
\end{tabular}


Odsjek sudjeluje i u organizaciji nekoliko znanstvenih skupova. Međunarodnu konferenciju LIDA (Libraries In the Digital Age) Odsjek organizira od 2002. godine u suradnji s Odjelom za informacijske znanosti Sveučilišta u Zadru i Školom za informacije i komunikaciju Sveučilišta Rutgers, SAD. Od 2013. Odsjek organizira i međunarodnu konferenciju Publishing Trends and Contexts u suradnji s Odjelom za informacijske znanosti Sveučilišta u Zadru, Udrugom Sa(n)jam knjige u Istri (do 2014.) i Goethe Institutom u Zagrebu i Centrom za obrazovno nakladništvo (od 2015.). Na tim konferencijama redovito sudjeluju i studenti s Odsjeka kao izlagači (predstavljaju svoje radove u obliku predavanja i postera), ali i kao članovi organizacijskog odbora pri čemu usvajaju važne praktične vještine. Odsjek je dvaput sudjelovao i u organizaciji međunarodne konferencije BOBCATSSS (22-24. 1. 2019. u Osijeku i 28.-30. 1. 2008. u Zadru) te međunarodne konferencije FEIS - Future of Education in Information Science, koja se 10-11. 9. 2018. održala u Pisi, Italija.

Članovi Odsjeka sudjeluju aktivno i unutar triju istraživačkih centara pri Filozofskom fakultetu Osijek (Centar za Internet i društvo, Centar za digitalnu etiku i Centar za knjigu i čitanje), čiji je cilj okupiti stručnjake u matičnoj ustanovi koji se zanimaju za proučavanje tema u okviru širokih istraživačkih područja.

\subsection{Izdavačka djelatnost Odsjeka}

Odsjek sve svoje aktivnosti od 2006. godine bilježi i objavljuje u obliku javno dostupne elektroničke publikacije pod nazivom Novosti Odsjeka za informacijske znanosti Filozofskog fakulteta u Osijeku. ${ }^{31}$ Uz Novosti, Odsjek je s Odjelom za informacijske znanosti Sveučilišta u Zadru pokretač časopisa Libellarium: časopis za istraživanje pisane riječi, knjige i baštinskih ustanova, a njegov glavni i odgovorni urednik od pokretanja 2008. do 2018. bio je Zoran Velagić. ${ }^{32}$ U izdanju Odsjeka do sada je izašlo nekoliko naslova (monografskih publikacija i zbornika radova), a njihov se popis nalazi u Prilogu 1.

\subsection{Stručna aktivnost Odsjeka}

Djelatnici Odsjeka aktivno sudjeluju u radu stručnih društava, prvenstveno Hrvatskog knjižničarskog društva (HKD), tako što održavaju predavanja za stručnu zajednicu, sudjeluju u radu stručnih tijela te redovito sudjeluju u različitim knjižničarskim projektima i skupovima. Članovi Odsjeka sudjeluju (ili su sudjelovali) u radu sljedećih radnih tijela i skupina unutar HKD-a: Komisija za knjižnične usluge

31 Usp. Novosti Odsjeka za informacijske znanosti Filozofskog fakulteta u Osijeku. Izdanja. [citirano: 2018-08-31]. Dostupno na: http://www.ffos.unios.hr/oziz/novosti/?page_id=2.

32 Usp. Libellarium. [citirano:2018-08-31]. Dostupno na: http://www.libellarium.org/index.php/ libellarium/about/contact. 
za djecu i mladež (Ivana Martinović), Komisija za teoriju i znanstveni rad (Sanjica Faletar Tanacković, Kornelija Petr Balog), Komisija za informacijske tehnologije (Boris Badurina i Boris Bosančić), Komisija za statistiku i pokazatelje uspješnosti u knjižnicama (Kornelija Petr Balog), Komisija za knjižnične usluge za osobe s invaliditetom i osobe s posebnim potrebama (Sanjica Faletar Tanacković), Komisija za zaštitu knjižnične građe (Damir Hasenay, Maja Krtalić, Ines Horvat), Povjerenstvo za izradu standarda za narodne knjižnice (Sanjica Faletar Tanacković), Radna skupina Hrvatskoga knjižničnog vijeća za izradu Pravilnika o stručnim zvanjima i napredovanju u knjižničarskoj struci (Kornelija Petr Balog) i Uredništvo mrežnih stranica (Boris Badurina, Sanjica Faletar Tanacković). Uz navedene aktivnosti u sekcijama, Kornelija Petr Balog obnaša dužnost glavne i odgovorne urednice časopisa Vjesnik bibliotekara Hrvatske od 2017. do danas, dok Boris Badurina uređuje mrežne stranice HKD-a.

Članovi Odsjeka aktivno sudjeluju u Nacionalnoj kampanji za osobe s teškoćama čitanja i disleksijom pod nazivom „I ja želim čitati“, čiji je glavni organizator HKD-ova Komisija za knjižnične usluge za osobe s invaliditetom i osobe s posebnim potrebama, ${ }^{33}$ a koja je prije svega usmjerena na osobe s disleksijom i teškoćama čitanja, odnosno na sve društvene skupine koje iz bilo kojeg razloga ne mogu čitati standardni, crni tisak te koristiti standardne knjižnične usluge.

Djelatnici Odsjeka aktivni su i na lokalnoj razini, u radu Društva knjižničara Slavonije, Baranje i Srijema (DKSBS), i to u sljedećim tijelima: Upravni odbor DKSBS-a (Ivana Martinović, Kornelija Petr Balog), Uredništvo mrežnih stranica DKSBS-a (Sanjica Faletar Tanacković), Povjerenstvo za određivanje kriterija za nagradu Marija Malbaša (Kornelija Petr Balog) te Urednički odbor časopisa Knjižničarstvo (Kornelija Petr Balog).

Vodstvo nacionalne stručne udruge Hrvatsko čitateljsko društvo bilo je u dva mandata povjereno članicama Odsjeka: Sanjici Faletar Tanacković od 2005. do 2007., te Maji Krtalić od 2007. do 2009.

Članovi Odsjeka aktivno sudjeluju i u radu međunarodnih stručnih udruga, a u pojedinima su obnašali vodeće funkcije:

- IFLA Education and Training Section: Kornelija Petr Balog (20052008.); IFLA Working Group on Prison Libraries: Sanjica Faletar Tanacković (od 2020.)

- Europski ogranak ASIST-a: Tatjana Aparac-Jelušić (predsjednica 20022009.)

- EUCLID (Europska udruga za knjižničarsko i informacijsko obrazovanje i istraživanje): Tatjana Aparac-Jelušić (predsjednica 2002-2009.)

33 Filozofski fakultet Osijek postao je 2019. godine službeni partner te kampanje. 


\subsection{Studenti}

$\mathrm{Na}$ Odsjeku za informacijske znanosti diplomski je studij završilo ukupno 626 studenata: ${ }^{34}$ od toga 259 na redovnom dvopredmetnom dodiplomskom studiju knjižničarstva (Osijek i Vinkovci), 161 na izvanrednom dopunskom studiju knjižničarstva (Zadar i Osijek), 178 na jednopredmetnom diplomskom studiju informatologije, 1 na združenom diplomskom studiju Pisana baština u digitalnom okruženju te 27 na dvopredmetnim diplomskim studijima Informatologije, Informacijske tehnologije i/ili Nakladništva (tablica 4).

Tablica 4. Diplomirani studenti po studijskim programima

\begin{tabular}{|c|c|}
\hline Studij & $\begin{array}{l}\text { Broj diplomi- } \\
\text { ranih studenata }\end{array}$ \\
\hline $\begin{array}{l}\text { Redovni dvopredmetni dodiplomski studij knjižničarstva } \\
\text { (Osijek) }\end{array}$ & 210 \\
\hline $\begin{array}{l}\text { Redovni dvopredmetni dodiplomski studij knjižničarstva (dis- } \\
\text { locirani studij Vinkovci) }\end{array}$ & 49 \\
\hline Izvanredni dopunski studij knjižničarstva (Osijek) & 96 \\
\hline Izvanredni dopunski studij knjižničarstva (Zadar) & 65 \\
\hline Jednopredmetnom diplomski studij Informatologije & 178 \\
\hline $\begin{array}{l}\text { Združeni diplomski studij Pisana baština u digitalnom } \\
\text { okruženju }\end{array}$ & 1 \\
\hline $\begin{array}{l}\text { Dvopredmetni diplomski studij Informatologije i Informacijske } \\
\text { tehnologije }\end{array}$ & 11 \\
\hline Dvopredmetni diplomski studij Informatologije i Nakladništva & 5 \\
\hline $\begin{array}{l}\text { Dvopredmetni diplomski studij Informacijske tehnologije i/ili } \\
\text { Nakladništva }\end{array}$ & 11 \\
\hline Ukupno & 626 \\
\hline
\end{tabular}

U akademskoj godini 2018/2019. na preddiplomskom je studiju Informatologije (na sve tri studijske godine) bilo upisano ukupno 112 studenata, a na diplomskom 85 (od toga 45 na Informatologiji, 50 na Informacijskoj tehnologiji, a 55 na Nakladništvu). Na temelju dostupnih podataka za spomenutu akademsku godinu može se zaključiti da je Preddiplomski studij Informatologije atraktivan među srednjoškolcima jer je omjer broja prijavljenih studenata i upisne kvote 3,07 : 1. Za 40 slobodnih studijskih mjesta (koliko je iznosila upisna kvota za 1. godinu

34 Stanje 24. srpnja 2020. 
preddiplomskog studija) prijavilo se ukupno 123 kandidata, pri čemu je za njih 40 studij Informatologije bio prvi izbor. Od 40 upisanih studenata, 19 je gimnazijalaca, a 21 ih je završilo strukovnu školu. Što se pak tiče diplomskih studija, interes studenata za studijske programe u ponudi Odsjeka najveći je u odnosu na sve ostale studijske programe koji se nude na Filozofskom fakultetu Osijek. Omjer broja prijavljenih i upisanih studenata za studij Nakladništva iznosi 2,32 (prijavljenih 58, upisano 25), Informatologije 2,35 (prijavljenih 47, upisano 20) te Informacijske tehnologije 2,04 (prijavljenih 51, upisano 25). ${ }^{35}$

Značajan dio obrazovnog iskustva studenata na Odsjeku zauzima praktična nastava, čija satnica raste kako studenti napreduju u studiju: na 1. i 2. godini preddiplomskog studija studenti imaju 6 sati prakse tjedno (90 sati ukupno), a na 3. godini 10 (jednopredmetni studij - 150 sati ukupno) odnosno 6 sati (dvopredmetni studij - 90 sati). Studenti svoju praksu najčešće odrađuju u informacijskim i baštinskim ustanovama, nakladničkim kućama te softverskim tvrtkama. Studenti dio svoje prakse na preddiplomskom studiju često odrađuju u okviru višegodišnjih projekata sređivanja baštinskih zbirki u samostanskim knjižnicama, ${ }^{36}$ a sve se češće odlučuju i za praksu u inozemstvu u okviru programa Erasmus.$+{ }^{37} \mathrm{Na}$ diplomskom studiju studenti nemaju klasičan praktični rad, nego u trećem semestru studija upisuju kolegij Projektni rad u informacijskim ustanovama, čiji je cilj primijeniti stečena znanja i vještine na određenom projektnom zadatku u odabranoj informacijskoj ustanovi, uz mentora u ustanovi radilištu i mentora-nastavnika. Satnica tog kolegija iznosi 4 sata tjedno (ukupno 60 sati). Kao što je razvidno iz naslova odabranih dosadašnjih projektnih radova, oni se temelje na principima društveno korisnog rada te pokušavaju pridonijeti kvaliteti knjižničnih usluga i obrazovnih iskustava te podići kvalitetu života u zajednici: Digitalizacija dijela zbirke ocjenskih radova Prehrambeno-tehnološkog fakulteta Osijek, Organizacija studentske konferencije InfoDASKA 2019, Digitalizacija časopisa u OŠ „Dobriša Cesarić“ u Osijeku, Mobilna aplikacija GISKO Članska iskaznica, Izrada mobilnih aplikacija za djecu s posebnim potrebama, Digitalna zbirka sitnog tiska u Muzeju Slavonije u Osijeku, Uređivanje specijalne zbirke župne knjižnice Višnjevac, Informacijska arhitektura mrežnih stranica Knjižnice Filozofskog fakulteta u Osijeku, Kreiranje web-stranice

35 Usp. Pon, L. Izvješće o kvaliteti nastave u ak. godini 2018./2019 na Filozofskom fakultetu Osijek. Osijek: Filozofski fakultet, 2019. [citirano: 2020-08-20]. Dostupno na: https://www.ffos. unios.hr/sustav-za-kvalitetu/izvjesca-ffos

36 Studenti su imali priliku sređivati zbirke u sljedećim spomeničkim knjižnicama: Knjižnica samostana u Blatu na Korčuli, Knjižnica Franjevačkog samostana u Mostaru, BiH, Knjižnica samostana sv. Ante u Dubravama, Brčko, BiH, Knjižnica franjevačkog samostana Tolisa, BiH, Knjižnica franjevačkog samostana na Plehanu, BiH i Knjižnica Isusovačkog kolegija u Dubrovniku.

$37 \mathrm{U}$ posljednjih 5 akademskih godina studenti su obavljali praksu u inozemnim ustanovama (knjižnicama, nakladničkim kućama, softverskim tvrtkama itd.) u Velikoj Britaniji, Irskoj, Sloveniji, Češkoj, Poljskoj i Njemačkoj. 
Udruge za samozastupanje Osijek, Uspostava digitalnog repozitorija e-prints knjižnice Filozofskog fakulteta u Osijeku, Promocija i uređenje zbirke Muzeja školjaka i ostalog morskog svijeta Udruge "Gloria Maris", Izrada vodiča kroz studij za buduće studente Odsjeka, Izrada digitalne zbirke Osječkim ulicama tragom zavičajnih pisaca, Izrada mrežne stranice Alumni kluba studenata Odsjeka za informacijske znanosti Filozofskog fakulteta Osijek, Izrada mobilne Android aplikacije FFOS Test Your Knowledge, Osmišljavanje aktivnosti i izrada edukativnih i promotivnih materijala za Tjedan zaštite baštine itd.

Kao dopuna praktičnoj nastavi, studente se tijekom studija potiče na aktivno sudjelovanje u izvannastavnim aktivnostima i volonterski, društveno koristan rad koji se najčešće ostvaruje kroz djelovanje Kluba studenata informacijskih znanosti Libros, ${ }^{38}$ osnovanog 2003. godine. Studenti u Klubu imaju priliku svoje iskustvo studiranja obogatiti sljedećim aktivnostima: sudjelovanje i izlaganje na domaćim i međunarodnim skupovima (npr. Festival znanosti, Kreativna riznica, LIDA, BOBCATSSS, CUC, INFuture, AKM seminar), ${ }^{39}$ organizacija konferencija (npr. InfoDASKA, BOBCATSSS), organizacija aktivnosti kojima se podiže kvaliteta života u zajednici (npr. kreativne igraonice u dječjem domu Klasje i na Pedijatriji KBC-a Osijek, programi poticanja čitanja u vrtićima), organizacija radionica i projekata koji pridonose razvoju i promociji informatičkih vještina (npr. STEM Kitteens, Robocode radionice s Lego Mindstorm robotima), organizacija radionica i projekata koji pridonose razvoju i promociji kulturne baštine (npr. Međunarodni dan muzeja, Noć muzeja, Noć knjige) te sudjelovanje u medijskim programima u svrhu promicanja studija i struke (npr. radijske i TV emisije), itd. O znanstveno-popularnim temama, aktualnoj problematici relevantnoj za studentski život te o svojim nastavnim i izvannastavnim aktivnostima, studenti pišu i objavljuju u svom časopisu Libros, koji uz podršku svojih nastavnika mentora (Jelena Lakuš, Josipa Selthofer, Mirna Gilman Ranogajec) samostalno stvaraju i uređuju od 2009. godine. Časopis Libros dobio je 2018. godine Rektorovu nagradu za izvrsnost i kvalitetu.

Studenti s Odsjeka dobili su tijekom godina brojne nagrade za svoj akademski uspjeh i/ili izvannastavne aktivnosti (tablica 5), a o prepoznatoj kvaliteti i uspješnosti studenata na Odsjeku ponajbolje govori podatak da je u ovom trenutku gotovo polovica zaposlenika na Odsjeku diplomirala upravo na Odsjeku.

\footnotetext{
38 Udruga je osnovana pod imenom Klub studenata knjižničarstva Libros, no 2006. s promjenom naziva Odsjeka došlo je i do promjene naziva u klubu studenata. Predsjednici Kluba bili su, kronološkim slijedom, sljedeći studenti: Marta Crljen, Drahomira Gavranović, Boris Kiš, Merien Gracek, Blaženka Čuić, Ivana Čadovska, Tanja Krstanović, Ema Čelebić, Lana Hrvatić i Antonela Čepčar.

39 Studenti s Odsjeka do sada su objavili nekoliko desetaka samostalnih radova i radova u suautorstvu s nastavnicima.
} 
Tablica 5. Nagrađeni studenti s Odsjeka

\begin{tabular}{|c|c|c|}
\hline Student & Nagrada & Godina \\
\hline Ena Maurus & $\begin{array}{l}\text { Pohvala Filozofskog fakulteta Osijek za us- } \\
\text { pješnost u studiranju (prosjek ocjena 4,917) }\end{array}$ & 2020. \\
\hline Marija Milošević & $\begin{array}{l}\text { Pohvala Filozofskog fakulteta Osijek za us- } \\
\text { pješnost u studiranju (prosjek ocjena 4,917) }\end{array}$ & 2020. \\
\hline Marija Milošević & $\begin{array}{l}\text { Prva nagrada za fotografiju na Natječaju za } \\
\text { najljepšu studentsku fotografiju na temu Sv- } \\
\text { jetskog dana voda (u okviru } 8 \text {. međunarodne } \\
\text { konferencije „Voda za sve“) }\end{array}$ & 2019. \\
\hline Jure Žilić & $\begin{array}{l}\text { Pohvala Filozofskog fakulteta Osijek za iz- } \\
\text { vannastavne aktivnosti }\end{array}$ & 2019. \\
\hline Mirjana Marković & $\begin{array}{l}\text { Pohvala Filozofskog fakulteta Osijek za } \\
\text { uspješnost u studiranju summa cum laude } \\
\text { (prosjek ocjena } 5,000 \text { ) }\end{array}$ & 2019. \\
\hline Mirjana Marković & Nagrada Zaklade Lions cluba Osijek & 2019. \\
\hline Jure Žilić & $\begin{array}{l}\text { Nagrada za najboljeg studenta volontera na } \\
\text { međunarodnoj konferenciji BOBCATSSS }\end{array}$ & 2019. \\
\hline $\begin{array}{l}\text { Vedrana Filić, Tena } \\
\text { Vilček i Mateja } \\
\text { Paradžik }\end{array}$ & $\begin{array}{l}\text { Nagrada za najbolji studentski rad na konfer- } \\
\text { enciji Libraries in the Digital Age (LIDA): } \\
\text { "The Role of Osijek Public Library in Mod- } \\
\text { ern Society: With Special Consideration of } \\
\text { Its Physical Accessibility" }\end{array}$ & 2018. \\
\hline $\begin{array}{l}\text { Josipa Iljić, Manu- } \\
\text { ela Orličnik, Ivana } \\
\text { Dejanović, Cvijetin } \\
\text { Vidaković, Elizabeta } \\
\text { Kotromanović i Iva } \\
\text { Magušić-Dumančić }\end{array}$ & Rektorova nagrada za časopis Libros & 2018. \\
\hline Ivana Dejanović & $\begin{array}{l}\text { Pohvala Filozofskog fakulteta Osijek za iz- } \\
\text { vannastavne aktivnosti }\end{array}$ & 2018. \\
\hline $\begin{array}{l}\text { Gabrijela Čuljak, Ivana } \\
\text { Jukić i Endrina Eskić }\end{array}$ & $\begin{array}{l}\text { Nagrada za najbolje izlaganje na studentskoj } \\
\text { konferenciji InfoDASKA } \\
\text { „Program otkupa knjiga Ministarstva kulture } \\
\text { i podaci o javnoj posudbi: mogućnosti ana- } \\
\text { lize“ }\end{array}$ & 2017. \\
\hline
\end{tabular}




\begin{tabular}{|c|c|c|}
\hline Student & Nagrada & Godina \\
\hline Ivona Palko & $\begin{array}{l}\text { Pohvala Filozofskog fakulteta Osijek za iz- } \\
\text { vannastavne aktivnosti }\end{array}$ & 2017. \\
\hline Nikolina Begović & $\begin{array}{l}\text { Rektorova nagrada za seminarski rad iz pred- } \\
\text { meta Informacijsko komunikacijska infras- } \\
\text { truktura pod nazivom „Korisničko iskustvo u } \\
\text { interakciji sa sustavom“ }\end{array}$ & 2017. \\
\hline $\begin{array}{l}\text { Dajana Stojanović, Ivo- } \\
\text { na Grgić, Željana Hrkač } \\
\text { i Luka Buljan }\end{array}$ & $\begin{array}{l}\text { 1. mjesto na CODEFEST hackatonu u Ko- } \\
\text { privnici }\end{array}$ & 2016. \\
\hline Mirna Marić & $\begin{array}{l}\text { Prva nagrada za aplikaciju Angler na nat- } \\
\text { jecanju App Start Contest s timom Bottom } \\
\text { Line }\end{array}$ & 2016. \\
\hline $\begin{array}{l}\text { Marta Matijević, } \\
\text { Domagoj Potlimbrzović } \\
\text { i Mateja Zuzjak }\end{array}$ & $\begin{array}{l}\text { Rektorova nagrada za pilot projekt „Izrada } \\
\text { mobilnih aplikacija za djecu s posebnim } \\
\text { potrebama“ u suradnji s Centrom za odgoj i } \\
\text { obrazovanje „Ivan Štark“ Osijek }\end{array}$ & 2016. \\
\hline Mirna Marić & $\begin{array}{l}\text { Prva nagrada za fotografiju na Natječaju } \\
\text { za najljepšu studentsku fotografiju na temu } \\
\text { Svjetskog dana voda (u okviru međunarodne } \\
\text { konferencije „Voda za sve) }\end{array}$ & 2016. \\
\hline Mirna Marić & $\begin{array}{l}\text { Nagrada za fotografiju na foto natječaju } \\
\text { „Sreća je..." u organizaciji fotografa Damira } \\
\text { Hoyke }\end{array}$ & 2016. \\
\hline Hana Marčetić & $\begin{array}{l}\text { Pohvala Filozofskog fakulteta Osijek za iz- } \\
\text { vannastavne aktivnosti }\end{array}$ & 2015. \\
\hline Hana Marčetić & $\begin{array}{l}\text { Rektorova nagrada za seminarski rad iz ko- } \\
\text { legija Informacijsko društvo pod nazivom } \\
\text { „Religija u informacijskom društvu“ }\end{array}$ & 2015. \\
\hline Domagoj Potlimbrzović & $\begin{array}{l}\text { Pohvala cum laude za završeni preddiploms- } \\
\text { ki studij (prosjek ocjena 4,571) }\end{array}$ & 2014. \\
\hline $\begin{array}{l}\text { Tanja Krstanović i Maja } \\
\text { Horvat }\end{array}$ & $\begin{array}{l}\text { Rektorova nagrada za seminarski rad iz } \\
\text { predmeta Teorija i praksa organizacije infor- } \\
\text { macija pod nazivom „Višejezično predmetno } \\
\text { označivanje““ }\end{array}$ & 2013. \\
\hline Maja Horvat & $\begin{array}{l}\text { Pohvala Filozofskog fakulteta Osijek za iz- } \\
\text { vannastavne aktivnosti }\end{array}$ & 2013. \\
\hline
\end{tabular}




\begin{tabular}{|c|c|c|}
\hline Student & Nagrada & Godina \\
\hline $\begin{array}{l}\text { Marija Primorac, } \\
\text { Ines Bobinac, Palma } \\
\text { Dizdarević, Rebeka } \\
\text { Đurišić, Sanja Glavak, } \\
\text { Ivana Lilijan, Mirela } \\
\text { Mihaljević i Sanja } \\
\text { Škugor }\end{array}$ & $\begin{array}{l}\text { Nagrada studentskog kapelana za humanitar- } \\
\text { no i etično ponašanje studenata, djelatnika i } \\
\text { organizacija Sveučilišta J. J. Strossmayera u } \\
\text { Osijeku za projekt „Uljepšaj mi dan“ KBC-a } \\
\text { Osijek Pedijatrija u okviru kolegija Mreže } \\
\text { narodnih knjižnica }\end{array}$ & 2012. \\
\hline Iva Sopka & $\begin{array}{l}\text { Rektorova nagrada za seminarski rad iz pred- } \\
\text { meta Teorija i praksa organizacije informaci- } \\
\text { ja pod nazivom „Korisničke oznake sadržaja } \\
\text { (tagovi) ili predmetne oznake knjižnica““ }\end{array}$ & 2011. \\
\hline Igor Ignjačić & $\begin{array}{l}\text { Nagrada za najbolji poster na konferenciji } \\
\text { Libraries in the Digital Age (LIDA): } \\
\text { Papić, A.; J. Selthofer; I. Ignjačić. Digital } \\
\text { native’s (in)formal learning environment }\end{array}$ & 2010. \\
\hline Marko Štrok & $\begin{array}{l}\text { Nagrada Lions cluba Osijek (prosjek ocjena } \\
4,77 \text { ) }\end{array}$ & 2008. \\
\hline $\begin{array}{l}\text { Merien Gracek, Kris- } \\
\text { tina Feldvari, Ivana } \\
\text { Knežević, Goran } \\
\text { Vučković i Filip Horvat }\end{array}$ & $\begin{array}{l}\text { Nagrada za najbolji poster na konferenciji } \\
\text { Libraries in the Digital Age (LIDA): } \\
\text { Bosančić, B.; B. Badurina; K. Petr; M. } \\
\text { Gracek; K. Feldvari; I. Knežević; G. } \\
\text { Vučković; F. Horvat. Students creating digi- } \\
\text { tal repository: students’ practical placement } \\
\text { at the department of information sciences, } \\
\text { faculty of philosophy in Osijek. // Librar- } \\
\text { ies in the Digital Age. Osijek: Filozofski } \\
\text { fakultet, 2007. }\end{array}$ & 2007. \\
\hline Mirjana Bučar & $\begin{array}{l}\text { Rektorova nagrada za seminarski rad „Kate- } \\
\text { gorija živosti u hrvatskom jeziku“ }\end{array}$ & 2006. \\
\hline Ivana Kukovec & $\begin{array}{l}\text { Rektorova nagrada za izvrstan seminarski } \\
\text { rad „Razvoj čitateljskih navika u obitelji - od } \\
\text { rođenja do ljubavi prema knjizi“ }\end{array}$ & 2005. \\
\hline Andrea Plavšić & $\begin{array}{l}\text { Pohvala Filozofskog fakulteta Osijek za us- } \\
\text { pješnost u studiranju (prosjek ocjena } 4,69 \text { ) }\end{array}$ & 2005. \\
\hline $\begin{array}{l}\text { Križak, Martina; } \\
\text { Mičunović, Milijana; } \\
\text { Radić, Magdalena }\end{array}$ & $\begin{array}{l}\text { Nagrada za najbolji poster na konferenciji } \\
\text { Libraries in the Digital Age (LIDA): } \\
\text { Koliko je popularna LIDA?: pokušaj webo- } \\
\text { metrijske analize citiranosti LIDA-e }\end{array}$ & 2003. \\
\hline
\end{tabular}




\section{Vrednovanje studijskih programa: rezultati istraživanja među studentima i poslodavcima}

Kako bi studijski programa u ponudi Odsjeka odgovarali na brze promjene na tržištu rada, na Odsjeku se redovito analizira studentska percepcija studijskih programa te vrednuju opseg i kvalitete usvojenih kompetencija. ${ }^{40}$ Prva takva studija provedena je 2008. godine u sklopu jednogodišnjeg projekta „Sustavni pristup uvođenju ishoda učenja u obrazovanje studenata na Sveučilištu Josipa Jurja Strossmayera u Osijeku“ (SUPER UNIOS), a cilj joj je bio utvrditi do koje se mjere kompetencije stečene tijekom studija podudaraju s očekivanjima i zahtjevima poslodavaca, odnosno radnog mjesta za koje su se studenti pripremali tijekom studija. Tim su istraživanjem bili obuhvaćeni studenti koji su studij dovršili po tzv. starom programu (prije prelaska na Bolonjski proces) i koji su diplomirali dvopredmetni studij (najčešće knjižničarstvo u kombinaciji s hrvatskim jezikom i književnošću, ali i pedagogijom, filozofijom, poviješću). Istraživanje je provedeno na širem prostoru Slavonije i Baranje, odnosno među onim ustanovama (prvenstveno visokoškolskim i narodnim knjižnicama) za koje se pretpostavljalo da zapošljavaju bivše studente Odsjeka. Poslodavci (ravnatelji narodnih i visokoškolskih knjižnica) u tom su istraživanju kao tri najvažnije kompetencije svojih djelatnika (diplomiranih studenata Odsjeka za informacijske znanosti Filozofskog fakulteta u Osijeku) naveli komunikativnost, pretraživanje i pronalaženje informacija te obradbu građe. Na temelju dobivenih podataka bilo je potom moguće izdvojiti najbolje i najlošije ocijenjene vještine naših studenata, prema mišljenju ispitanika. Ravnatelji narodnih knjižnica najbolje su ocijenili njihove vještine pretraživanja i pronalaženja informacija, tehnička znanja i vještine te organizacijske sposobnosti, a visokoškolskih komunikativnost, tehnička znanja i vještine, organizacijske sposobnosti te poznavanje stranih jezika. Tri najlošije ocijenjene kompetencije za narodne knjižnice bile su digitalizacija građe, poznavanje stranih jezika i samostalnost u radu, a za visokoškolske pretraživanje i pronalaženje informacija, obradba građe, digitalizacija i samostalnost u radu. Dobiveni su podaci pokazali da su ispitani poslodavci u pravilu zadovoljni ishodima učenja i kompetencijama svojih djelatnika koji su se obrazovali na Odsjeku za informacijske znanosti Filozofskog fakulteta Osijek. Naime, zadovoljstvo njihovim vještinama i znanjima općenito ravnatelji narodnih knjižnica ocijenili su ocjenom 4,4, a visokoškolskih 4,5. Provedeno je pak istraživanje ukazalo da postoje kompetencije kojima do tada nije bilo posvećeno dovoljno pozornosti, odnosno uočena su područja koja treba intenzivnije uključiti u studijske programe. ${ }^{41}$

40 O važnosti knjižničarskih kompetencija (područno-specifičnih i generičkih) pogledati u Machala D. Knjižničarske kompetencije: pogled na razvoj profesije. Zagreb: Hrvatska sveučilišna naklada; Nacionalna i sveučilišna knjižnica, 2015.

${ }^{41}$ Usp. Petr Balog, K.; I. Martinović. Na tragu ishoda učenja : kompetencije diplomiranih knjižničara Odsjeka za informacijske znanosti u Osijeku. // Vjesnik bibliotekara Hrvatske 52, 1-4(2009), 1-17. [citirano:2020-08-27]. Dostupno na: https://www.hkdrustvo.hr/vjesnik-bibliotekara-hrvatske/index.php/vbh/article/view/457/452. 
Godine 2015. provedeno je istraživanje čija je svrha bila procijeniti kako su studenti koji su diplomirali na Odsjeku pripremljeni za tržište rada te ispitati njihove stavove i mišljenja vezano uz zapošljavanje, zadovoljstvo studijem te znanjima stečenim tijekom studija. Većina od ukupno 58 magistara informacijskih znanosti koji su sudjelovali u istraživanju istaknuli su da su zadovoljni stečenim znanjima iz područja komunikacije i nakladništva, no tek su djelomično zadovoljni znanjima iz područja rada s bazama podataka, knjižničnog poslovanja i organizacije informacija. U odnosu na područje knjižničnog poslovanja ispitanici su izrazili visok stupanj zadovoljstva s osam (istraživanje korisničke zajednice i potreba korisnika, ulaganje knjiga na police, timski rad i preuzimanje uloge voditelja u timu, poznavanje i korištenje referentne građe te zaštita knjižnične građe i podataka, poznavanje etičkih načela, zakonske regulative i normi koje se primjenjuju u struci, zaštita elektroničke građe te izgradnja knjižničnog fonda), a niži stupanj zadovoljstva s četiri potpodručja (vrednovanje uspješnosti poslovanja tvrtke ili organizacije, rad na posudbenom odjelu, tehnička obrada građe i rad u računalnim programima za knjižnično poslovanje). U odnosu na područje organizacije informacija ispitanici su tri potpodručja ocijenili visokim stupnjem zadovoljstva (pronalaženje, evaluacija i upotreba informacija u svim oblicima, katalogizacija knjižne građe te organizacije bibliografskih i kataložnih informacija), dok su za tri potpodručja (organizacija, kreiranje i pretraživanje digitalnih zbirki, digitalizacija knjižnične građe te katalogizacija neknjižne građe) iskazali niži stupanj zadovoljstva ${ }^{42}$ Valja istaknuti da su u tom istraživanju studenti koji su diplomirali prije 2011. godine $e^{43} \mathrm{u}$ većoj mjeri bili zadovoljni studijem općenito (50\%), od onih koji su diplomirali 2012. i kasnije (23,9\%). Zanimljivo je, nadalje, da velik broj ispitanika smatra da volontiranje u ustanovama tijekom studija daje prednost pri zapošljavanju te da se gotovo polovica ispitanika susrela s nekim oblikom diskriminacije i nepravednog zapošljavanja drugih kandidata. Rezultati dobiveni tim istraživanjem, koji su ukazali na umjereno zadovoljstvo, odnosno nedostatnu razinu zadovoljstva diplomiranih studenata studijskim programom i stečenim znanjima i vještinama, te posljedično njihovom nedostatnom pripremljenošću za tržište rada, potvrdili su već prepoznatu potrebu za ponovnom revizijom studijskih programa kojoj se pristupilo akademske godine 2015/2016. ${ }^{44}$

\footnotetext{
42 Ispitanici su bili u najvećoj mjeri zadovoljni znanjima i vještina iz područja organizacije bibliografskih i kataložnih informacija, korištenje referentne građe, vrednovanje uspješnosti poslovanja tvrtke ili organizacije i istraživanje korisničke zajednice i potreba korisnika. U najmanjoj su mjeri bili zadovoljni poznavanjem rada u računalnim programima za knjižnično poslovanje.

43 To su u pravilu studenti koji su studirali po starom programu, prije bolonjskih studijskih programa.

44 Usp. Dukić, G.; T. Jozinović. Upravljanje znanjem na Sveučilištu: Pripremljenost magistara informacijskih znanosti s Filozofskog fakulteta u Osijeku za tržište rada. // Tehnički glasnik, 10, 1-2(2016), str. 22-28. Rad se temelji na diplomskom radu studentice T. Jozinović, Spremnost magistara informatologije Odsjeka za informacijske znanosti u Osijeku za tržište rada, izrađenim pod mentorstvom Gordane Dukić te obranjenom 21. 9. 2015.
} 
Tijekom 2018. godine provedena su dva istraživanja $\mathrm{a}^{45}$ među studentima 1. i 3. godine preddiplomskog studija na Odsjeku kojima se pokušalo utvrditi kako ispitanici percipiraju odabranu profesiju i studijski program, zašto su upisali studij te koja su im očekivanja od karijere. ${ }^{46}$ Oba su istraživanja potvrdila da je studij informatologije još uvijek pretežno ženski studij s otprilike $20 \%$ muške populacije, a zanimljivo je da je na obje ispitane generacije za tek otprilike polovicu ispitanika studij informatologije bio prvi izbor, odnosno željeni studij. Iako je oko $70 \%$ ispitanika u obama istraživanjima odluku o upisu na studij donijelo pred sam kraj svog srednjoškolskog obrazovanja i/ili neposredno pred sam upis na studij, odgovori ispitanika koji su upisani na 3. godinu studija pokazuju da je studij uspio pridobiti većinu ,zalutalih“ studenata jer planiraju ili nastaviti diplomsko obrazovanje ili potražiti zaposlenje u tom području. Značajan broj ispitanika odabrao je ovaj studij zbog raznolikih mogućnosti zapošljavanja nakon diplomskog studija iz tog područja (47,8 $\%{ }^{47}$ i $30 \%{ }^{48}$ ispitanika). Podaci dobiveni u komparativnoj studiji, koja je uključila starije studente, pokazuju da ispitanici smatraju najvažnijim sljedeća znanja i vještine koje se usvajaju na studiju: informacijska pismenost, informacijsko ponašanje, pretraživanje i pronalaženje informacija, IT vještine, organizacija informacija, komunikacijske vještine. $U$ objema su studijama ispitanici istaknuli važnost praktičnog rada u obrazovanju i pripremi za tržište rada, pri čemu $91,3 \%$ studenata 3 . godine smatra da u studijski program treba ugraditi više prakse, a $69,9 \%$ ih smatra da veći naglasak treba staviti na IT kolegije. Otprilike trećina ispitanika izjavila je da bi voljela da se studij nudi u dvopredmetnoj kombinaciji, sa studijima na nekim drugim odsjecima. 60,9 \% ispitanika zadovoljno je kako ih studij priprema za tržište rada i vjeruje da neće imati problema pri pronalaženju posla (iako ih 30,4 \% smatra da su opcije koje se nude na tržištu nepovoljne/nedostatne). Valja istaknuti na kraju da je ukupno 60,9 \% ispitanika s 3. godine preddiplomskog studija istaknulo da bi ponovo izabrali ovaj studij kad bi

45 U prvom je istraživanju provedena komparativna studija među studentima na osječkom Odsjeku za informacijske znanosti i na istovjetnom odjelu na turskom sveučilištu Hacettepe. U ovom će se radu predstaviti samo oni rezultati iz navedenog komparativnog istraživanja koji se odnose na osječke studente.

${ }^{46}$ Faletar Tanacković, S.; J. Žilić; S. Kurbanoglu; Y. Unal. Student perceptions of LIS programs and profession: study among undergraduates in Croatia and Turkey. // The Future of Education in Information Science Proceedings from FEIS - International EINFOSE Symposium, 10-11 September 2018 Pisa, Italy / edited by Tatjana Aparac-Jelušić, Vittore Casarosa and Elena Macevičiūtè. Osijek: Faculty of Humanities and Social Sciences, University of Osijek, 2018. Str. 46-61. [citirano: 2020-08-20]. Dostupno na: http://einfose.ffos.hr/feis-2018/proceedings i Faletar Tanacković, S.; K. Petr Balog. Percepcija knjižničarskog i informacijskog studija i profesije: rezultati pilot istraživanja među studentima preddiplomskog sveučilišnog studija Informatologije na Filozofskom fakultetu Sveučilišta u Osijeku. // Zbornik radova 3. stručnog skupa s međunarodnim sudjelovanjem „Zanimanje: knjižničar“. Beli Manastir, 9. 11. 2018. Beli Manastir: Gradska knjižnica Beli Manastir, 2018. Str. 248-260.

47 Faletar Tanacković, S.; J. Žilić; S. Kurbanoglu; Y. Unal. Nav. dj.

48 Faletar Tanacković, S.; K. Petr Balog. Nav. dj. 
birali profesiju ispočetka, a među onima koji bi ipak izabrali nešto drugo izdvajaju se oni koji smatraju da je u studijskom programu previše knjižničarskih sadržaja, odnosno da je premalo kolegija posvećenih IT-u (bilo u teorijskom ili praktičnom smislu). Upravo zahvaljujući redovitim evaluacijama svojih studijskih programa, otvorenošću i uključivanju svih zainteresiranih dionika (prvenstveno studenata i poslodavaca) u promišljanja o njihovim potrebnim izmjenama i dopunama, Odsjek uspijeva održati visok stupanj zainteresiranosti među potencijalnim kandidatima, te sve više privlačiti i studente koji ne dolaze iz neposrednog okruženja.

\section{Zaključak}

Cilj ovoga rada bio je predstaviti djelovanje Odsjeka za informacijske znanosti Filozofskog fakulteta u Osijeku, od osnutka do danas, kroz njegovu znanstvenu, nastavnu i stručnu djelatnost, studijske programe te studentsku populaciju.

Zahvaljujući mladom i visokomotiviranom osoblju, sa širokim interdisciplinarnim interesima i obrazovanjem, Odsjek već više od 20 godina nudi visokokvalitetne studijske programe u području informacijske i komunikacijske znanosti, koji se kontinuirano prilagođavaju najnovijim spoznajama u području, potrebama na (globalnom) tržištu rada, očekivanju poslodavaca te mišljenju studenata. Kvaliteta obrazovnog iskustva na Odsjeku, koja proizlazi iz utemeljenost nastave na najnovijim znanstvenim i stručnim, ali i pedagoškim spoznajama i njezinoj prilagodljivosti u brzo mijenjajućim uvjetima, jedan je od ključnih preduvjeta za prepoznatljivost završenih studenata na tržištu rada, i njihovu zapošljivost i izvan Osječko-baranjske županije, pa čak i Hrvatske.

Odsjek, nadalje, pridaje posebnu važnost uključivanju najboljih studenata u znanstvene projekte (u funkciji suradnika) te u stručne i izvannastavne aktivnosti, za što nerijetko bivaju nagrađeni od strane Fakulteta, Sveučilišta i drugih relevantnih ustanova. Zahvaljujući Klubu studenata Libros, i uz podršku nastavnika, brojni studenti tijekom svog studija stječu bogata znanja, vještine i iskustva vezana uz organizaciju skupova, oblikovanje i izdavanje časopisa, pisanje i javno izlaganje radova, prenošenje spoznaja i društveno koristan rad itd.

Iz analize djelovanja Odsjeka vidljivo je da djelatnici Odsjeka svojim stalnim angažmanom i naporima razvijaju i bogatu stručnu i znanstvenu djelatnost te da je njihova kvaliteta prepoznata u Republici Hrvatskoj, ali i van nje, što potvrđuju brojna priznanja za njihovu znanstvenu izvrsnost. Ovdje svakako treba istaknuti da je u svibnju 2019. Odsjek, kao za sada jedini predstavnik Hrvatske, primljen u prestižnu međunarodnu grupaciju iSchools, koja okuplja ponajbolje škole iz područja informacijske i komunikacijske znanosti iz čitavog svijeta.

Vjerujemo da otvorenost Odsjeka prema novim idejama i kontinuirano visoka zainteresiranost studenata za ponuđene studijske programe potvrđuje spremnost 
Odsjeka da odgovori na izazove koje pred visokoškolsko obrazovanje postavlja 21. stoljeće i ostvari svoju temeljnu zadaću obrazovanja stručnjaka koji će biti sposobni promišljati i unaprjeđivati kvalitetu ljudskog života, uzimajući u obzir razvijanje funkcionalnih pismenosti, njegovanje navika kritičkog čitanja i razmišljanja, osiguravanju pristupa relevantnim, kvalitetnim i pouzdanim informacijama te uopće izgradnji društva u kojemu će nesagledive mogućnosti informacijske i komunikacijske tehnologije obogatiti i poslovanje i slobodno vrijeme građana.

\section{LITERATURA}

Aparac-Gazivoda, T.; A. Horvat. Dodiplomsko obrazovanje bibliotečnih i ostalih informacijskih stručnjaka. // Obrazovanje za tehnološki razvoj:Savjetovanje Zagreb: Savez inženjera i tehničara, 1985. Str. 181-188.

Aparac-Jelušić, T. Kompetencije knjižničara i informatologa: izazovi u vremenu društvenih i kulturnih promjena. // Organizacija znanja 24, 1-2(2019), 1-12. [citirano: 2020-07-22]. Dostupno na: https://www.cobiss.si/OZ/PDF/OZ_2019_1_2_final/1924001_Aparac_Jelusic.pdf.

Aparac-Gazivoda, T. Teorijske osnove knjižnične znanosti. Zagreb: Filozofski fakultet, Zavod za informacijske studije Odsjeka za informacijske znanosti, 1993.

Dukić, G.; T. Jozinović. Upravljanje znanjem na Sveučilištu: pripremljenost magistara informacijskih znanosti s Filozofskog fakulteta u Osijeku za tržište rada. // Tehnički glasnik 10, 1-2(2016), 22-28.

Erl, V.; K. Petr. Studij bibliotekarstva na Pedagoškom fakultetu u Osijeku: da ili ne? // Vjesnik bibliotekara Hrvatske 39, 1-2(1996), 163-170.

Faletar Tanacković, S.; J. Žilić; S. Kurbanoglu; Y. Unal. Student perceptions of LIS programs and profession: study among undergraduates in Croatia and Turkey.//The Future of Education in Information Science Proceedings from FEIS - International EINFOSE Symposium, 10-11 September 2018 Pisa, Italy / edited by Tatjana Aparac-Jelušić, Vittore Casarosa and Elena Macevičiūtè. Osijek: Faculty of Humanities and Social Sciences, University of Osijek, 2018. Str. 46-61. [citirano: 2020-08-20]. Dostupno na: http://einfose.ffos.hr/feis-2018/proceedings

Faletar Tanacković, S.; K. Petr Balog. Percepcija knjižničarskog i informacijskog studija i profesije: rezultati pilot istraživanja među studentima preddiplomskog sveučilišnog studija Informatologije na Filozofskom fakultetu Sveučilišta u Osijeku. // Zbornik radova 3. stručnog skupa s međunarodnim sudjelovanjem "Zanimanje: knjižničar”. Beli Manastir, 9. 11. 2018. Beli Manastir: Gradska knjižnica Beli Manastir, 2018. Str. 248-260.

Horvat, A. Školovanje i izobrazba bibliotekara pred novim tisućljećem. // Vjesnik bibliotekara Hrvatske 40, 1/2(1997), 131-138. 
Horvat, A. Školovanje knjižničara u Hrvatskoj. // Vjesnik bibliotekara Hrvatske 39, 1/2(1996), 133-142.

Horvat, A. Školovanje knjižničara u svjetlu europskih normi. // Vjesnik bibliotekara Hrvatske 48, 1(2005), 101-106.

Horvat, A. Obrazovanie i vospituvanje bibliotekari na početokot na noviot vek. // Bibliotekarska iskra 17, 1/2(1999), 37-41.

Horvat, A.; J. Kolanović; V. Zgaga. Croatia: Libraries, archives and museums. // Encyclopedia of Library and Information Sciences / ed. by M. J. Bates, M. N. Maack. 3rd. ed. Clevelnad: CRC Press, 2009. Str. 1345-1355.

Izvještaj o radu u školskoj godini 1968./69. Osijek: Pedagoška akademija, 1969.

Machala D. Knjižničarske kompetencije: pogled na razvoj profesije. Zagreb: Hrvatska sveučilišna naklada; Nacionalna i sveučilišna knjižnica, 2015.

Odjel za informacijske znanosti: samoanaliza. Zadar: Sveučilište, 2014. [citirano: 201808-28]. Dostupno na: http://iz.unizd.hr/Portals/70/docs_stari_web/sa_starog_weba_ ZG/SAMOANALIZA_OIZ_FIN_potpis.pdf.

Odsjek za informacijske znanosti. Studijski programi. // Filozofski fakultet Osijek. [citirano:2018-08-30]. Dostupno na: http://www.ffos.unios.hr/infoznanosti/studijski-programi.

Ole Pors, N. Library education. // International Encyclopedia of Information and Library Science / ed. by J. Feather and P. Sturges. London; New York: Routledge, 2003. Str. 381-383.

Petr Balog, K. Osnutak Katedre za knjižničarstvo, Pedagoški fakultet Osijek: (ak. god. 1998./1999.). // Knjižničarstvo 13-14, 1-2(2009-2010), 26-28.

Petr Balog, K.; I. Martinović. Na tragu ishoda učenja: kompetencije diplomiranih knjižničara Odsjeka za informacijske znanosti u Osijeku. // Vjesnik bibliotekara Hrvatske 52, 1-4(2009), 1-17. [citirano: 2020-08-20]. Dostupno na: https://www.hkdrustvo. hr/vjesnik-bibliotekara-hrvatske/index.php/vbh/article/view/457/452

Pon, L. Izvješće o kvaliteti nastave u ak. godini 2018./2019 na Filozofskom fakultetu Osijek. Osijek: Filozofski fakultet, 2019. [citirano: 2020-08-20]. Dostupno na: https://www.ffos.unios.hr/sustav-za-kvalitetu/izvjesca-ffos

Radman, Lj. Osvrt na školovanje knjižničara u Osijeku od 1977. do 1990. godine. // Knjižničarstvo 1, 1(1997), str. 64-73. [citirano: 2018-08-28]. Dostupno na: http:// www.knjiznicarstvo.com.hr/wp-content/uploads/2012/06/6_Radman_1997_1.pdf.

Rubin, R. E. Foundations of library and information science. London: Facet, 2016. 


\section{Prilog 1.}

\section{Izdanja Odsjeka za informacijske znanosti Filozofskog fakulteta u Osijeku}

Aparac-Jelušić, T.; S. Faletar Tanacković. Knjižnična arhitektura: prostor, kultura, identitet. Zagreb: Ljevak, 2020.

Clark, G.; A. Phillips. O nakladništvu iznutra / preveli studenti diplomskog studije anglistike FF Osijek. Zagreb: Hrvatska sveučilišna naklada; Osijek: Filozofski fakultet, 2017.

Erl Šafar, M. Razvoj pokretnih knjižnica u Republici Hrvatskoj. Osijek: Odjel za kulturologiju Sveučilišta; Matica hrvatska, Ogranak Osijek, 2018.

The future of education in information science: Proceedings from FEIS - International EINFOSE Symposium, 10-11 September 2018 Pisa, Italy / edited by Tatjana Aparac-Jelušić, Vittore Casarosa and Elena Macevičiūtè. Osijek: Faculty of Humanities and Social Sciences, University of Osijek, 2018. ISBN: ISBN 978-953-314-120-6. Dostupno na: http://einfose.ffos.hr/feis-2018/proceedings.

Izazovi pisane baštine: zbornik radova u povodu 75. obljetnice života Aleksandra Stipčevića / urednica Tatjana Aparac-Jelušić. Osijek: Filozofski fakultet, 2005.

Libraries in the Digital Age (LIDA) Proceedings / Pehar, Franjo (Ed.). Zadar: University of Zadar, Department of Information Sciences; Osijek: University of Osijek, Faculty of Humanities and Social Sciences, 2012. ISBN: 978-953-331-062-6 Dostupno na: http://ozk.unizd.hr/proceedings/index.php/lida2012/article/view/10/16.

Libraries in the Digital Age (LIDA) Proceedings / Bosančić Boris and Sanjica Faletar Tanacković (Eds.). Zadar: University of Zadar, Department of Information Sciences; Osijek: University of Osijek, Faculty of Humanities and Social Sciences,, 2014. ISBN: 978-953-314-077-3 Dostupno na: http://ozk.unizd.hr/proceedings/index.php/ lida/article/view/114/116.

Novosti Odsjeka za informacijske znanosti (godišnja publikacija). Br. 1(2006). Dostupno na: https://www.ffos.unios.hr/oziz/novosti/?page_id=2. [citirano: 2020-07-17]

Ogledi o informacijskim znanostima: zbornik radova u čast Tatjane Aparac-Jelušić / uredile Martina Dragija Ivanović i Sanjica Faletar Tanacković. Osijek: Filozofski fakutet; Zadar: Sveučilište, 2016.

Petr Balog, K. Prema kulturi vrednovanja u visokoškolskim knjižnicama. Osijek: Filozofski fakultet, 2010.

Saracevic, T. Prilozi utemeljenju informacijske znanosti / urednica Tatjana Aparac-Jelušić. Osijek: Filozofski fakultet, 2006.

Tadić, K. Bibliografija o arhivima, čitaonicama, knjižnicama i muzejima: napisi iz riječkih i sušačkih hrvatskih novina od 1900. do 1999., na području današnjih županija Primorsko-goranske, Istarske i Ličko-senjske / urednica Tatjana Aparac-Jelušić. Osijek: Filozofski fakultet, 2005.

Velagić, Z. Pisac i autoritet: bit autorstva i sustav autorizacije vjerskih knjiga u 18. stoljeću. Zagreb: Naklada Ljevak, 2010.

Velagić, Z. Uvod u nakladništvo. Osijek: Filozofski fakultet, 2013.

Velagić, Z.; T. Jakopec; F. Pehar; J. Selthofer. Elektroničko nakladništvo? Zagreb: Naklada Ljevak, 2017. 